\title{
A Case of Leser-Trélat Syndrome Associated with a Renal Cell Carcinoma
}

\author{
Dietrich Barth $^{\mathrm{a}}$ Silvio Puhlmann ${ }^{\mathrm{b}}$ Joachim Barth \\ ${ }^{a}$ Praxis für Haut- und Geschlechtskrankheiten Dr. Barth Leipzig/Borna, and ${ }^{\mathrm{b}}$ Klinik für \\ Urologie - Sana Klinikum Borna, Borna, Germany
}

\section{Key Words}

Leser-Trélat syndrome · Seborrheic keratoses · Paraneoplastic · Renal cell carcinoma

\begin{abstract}
Seborrheic keratoses can often be found in elderly people. In general, they appear gradually. In cases of a sudden eruption with itching it might be paraneoplastic. Although some authors doubt the existence of the paraneoplastic Leser-Trélat syndrome, we present a case of sudden eruption of seborrheic keratoses connected with a newly diagnosed renal cell carcinoma. As far as we know, this is the first case report of a Leser-Trélat syndrome with a malignancy of the kidney.

\section{Introduction}

The Leser-Trélat syndrome (LTS) is a paraneoplastic syndrome of the skin. It shows typical clinical features with a sudden eruption of pruritic seborrheic keratoses in association with a carcinoma but it is questioned by some authors. Beside the paraneoplastic LTS, two other entities are known as pseudo-syndromes of LTS: associated with chemotherapy often with epidermal growth factor (EGF) antagonists, and more rarely, cases of the syndrome without any malignancies. We report the case of a 'classical' LTS associated with a renal carcinoma. 


\section{Case Reports in Dermatology}

Barth et al.: A Case of Leser-Trélat Syndrome Associated with a Renal Cell Carcinoma

\section{Case Presentation}

The 68-year-old female patient presented with an eruptive appearance of seborrheic keratoses within 4 weeks (fig. 1a). She also reported an unusual itching of these newly developed keratoses.

Shortly before, she was referred to vascular surgery because of episodes of claudicatio intermittens. A stenosis of the arteria femoralis was diagnosed as well as a renal tumor of the left kidney (fig. 1b). Histology showed a well-differentiated clear cell renal cell carcinoma (fig. 1c).

Because of reported cases with a variety of different cancer types associated with LTS [1], we asked our patient to undergo a staging. Besides being under control by urology she presented to gynecology without any malignant findings. A chest X-ray as well as an ultrasound of the abdomen, coloscopy and gastroscopy were normal. Also, blood tests showed no signs of abnormalities. Therefore, we excluded other possible malignancies.

\section{Discussion}

In dermatology, a number of paraneoplastic skin changes are known. Acanthosis nigricans, acrodermatitis Bazex, erythema gyratum repens (Gammel), dermatomyositis, or extramammary Paget's disease are familiar paraneoplastic syndromes. They can be facultative or obligate paraneoplastic skin changes.

LTS is named after Edmund Leser and Ulisse Trélat. The most frequently associated carcinomas are adenocarcinomas like gastrointestinal cancers. Also, the first case reports described associated gastrointestinal cancers [2,3]. LTS can also be associated with cancers of the breast, lung, liver, pancreas, hematopoietic neoplasm or prostate $[4,5]$. The number of reported renal cancers is extremely small. On the other hand, patients with typical dermatological features of LTS without any malignancies during a prolonged follow-up period raised questions about the existence of LTS and led to reviews concerning the reported cases [6].

The pathomechanism leading to an eruption of seborrheic keratoses is so far unknown. There are different hypotheses. One links the eruption to human papillomaviruses as can be seen in immunocompromised patients with HIV [7]. Another one features the theory of growth factors like the EGF produced by tumor cells or tumor tissue that has an impact of the development of seborrheic keratoses [8]. This theory - until proven wrong - is also our favorite explanation of this syndrome. Other studies on seborrheic keratoses found no difference in EGF receptor expression between healthy controls and patients with a malignancy [9]. We know that seborrheic keratoses are often associated with a family history of these skin changes. Thus, they might be induced by FGFR3 and PIK3CA-mutations that can lead to multiple keratoses in all ages and genders [10].

\section{Conclusion}

This case of LTS associated with a renal carcinoma shows that also the urogenital system should be inspected carefully when a LTS is suspected. Some authors are questioning the existence of the LTS because elderly patients often suffer from seborrheic keratoses. But the sudden eruption of seborrheic keratoses in association with unusual itching and a before unknown carcinoma could lead to understand it as a special syndrome. 
Barth et al.: A Case of Leser-Trélat Syndrome Associated with a Renal Cell Carcinoma

\section{Acknowledgements}

We would like to thank the Institute of Pathology of the University of Leipzig for the histological pictures. Also, we thank the Sana Klinikum Borna for the CT scan of the abdomen.

\section{Statement of Ethics}

The authors declare that the patient has given her informed consent.

\section{Disclosure Statement}

The authors declare no financial disclosures.

\section{References}

1 Ponti G, Luppi G, Losi L, Giannetti A, Seidenari S: Leser-Trélat syndrome in patients affected by six multiple metachronous primitive cancers. J Hematol Oncol 2010;3:2.

2 Leser E: Über ein die Krebskrankheit beim Menschen häufig begleitendes, noch wenig gekanntes Symptom. Munch Med Wochenschr 1901;51:2035-2036.

-3 Hollander EV: Beitrage zur Frühdiagnose des Darmcarcinomas (Hereditätsverhältnisse und Hautveränderungen) Dtsch Med Wochenschr 1900;26:483-485.

4 Lindelöf B, Sigurgeirsson B, Melander S: Seborrhoeic keratoses and cancer. J Am Acad Dermatol 1992;26:947-950.

5 Schwengle LE, Rampen FH, Wobbes T: Seborrhoeic keratoses and internal malignancies. A case control study. Clin Exp Dermatol 1988;13:177-179.

6 Turan E, Yesilova Y, Yurt N, Koçarslan S: Leser-Trélat sign: does it really exist? Acta Dermatovenerol Croat 2013;21:123-127.

7 Inamadar AC, Palit A: Eruptive seborrhoeic keratosis in human immunodeficiency virus infection: a coincidence or 'the sign of Leser-Trélat'? Br J Dermatol 2003;149:435-443.

8 Ellis DL, Kafka SP, Chow JC, Nanney LB, Inman WH, McCadden ME, King LE Jr: Melanoma, growth factors, acanthosis nigricans, the sign of Leser-Trélat, and multiple acrochordons: a possible role of alphatransforming growth factor in cutaneous paraneoplastic syndromes. N Engl J Med 1987;317:1582-1587.

-9 Jepsen RK, Skov AG, Skov BG: Leser-Trélat syndrome in malignant mesothelioma and pulmonary adenocarcinoma: is the EGFR pathway part of the syndrome? Virchows Arch 2014;464:117-120.

10 Logié A, Dunois-Lardé C, Rosty C, Levrel O, Blanche M, Ribeiro A, Gasc JM, Jorcano J, Werner S, Sastre-Garau $\mathrm{X}$, Thiery JP, Radvanyi F: Activating mutations of the tyrosine kinase receptor FGFR3 are associated with benign skin tumors in mice and humans. Hum Mol Genet 2005;14:1153-1160. 

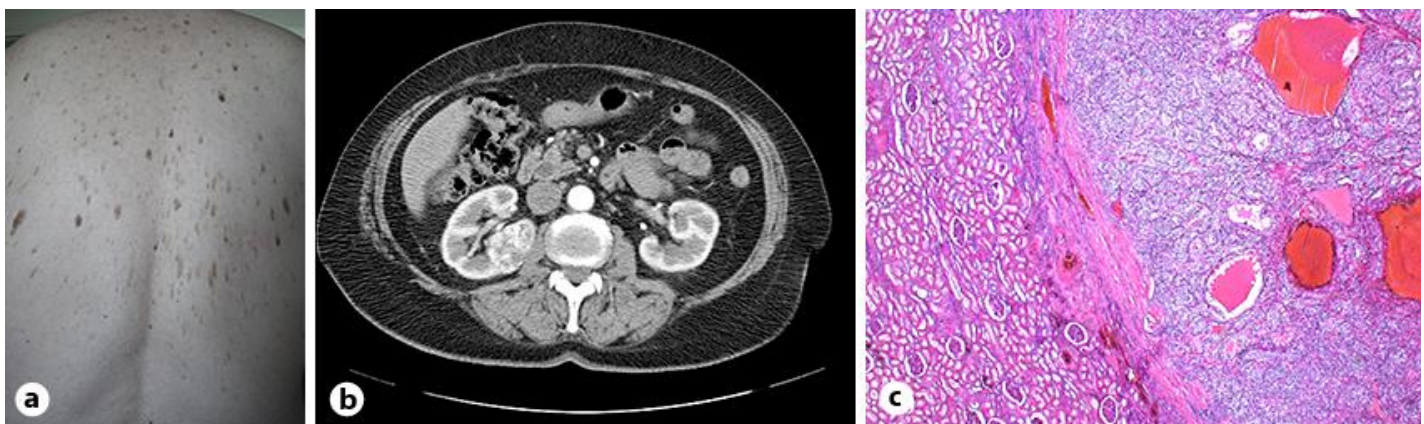

Fig. 1. a Clinical picture of the back shortly after the eruption of the seborrheic keratoses. $\mathbf{b}$ Left kidney with tumor as seen while under diagnostic treatment for episodes of claudicatio intermittens. c HE stain of the clear cell renal cell carcinoma of our patient (left: normal kidney; right: tumor). $\times 25$. 